\title{
Educational Experiences of the International Students in Graduate Programs in Turkey
}

\author{
Yusuf Alpaydin ${ }^{1}$ \\ ${ }^{1}$ Ataturk Education Faculty, Marmara University, Istanbul, Turkey \\ Correspondence: Yusuf Alpaydin, Ataturk Education Faculty, Marmara University, Istanbul, Turkey. Tel: \\ 90-216-345-9090. E-mail: yusufalp@gmail.com
}

Received: November 8, 2017

Accepted: November 30, 2017 Online Published: December 21, 2017

doi:10.5539/jel.v7n2p89

URL: http://doi.org/10.5539/jel.v7n2p89

\begin{abstract}
Educational quality determined by factors such as academic climate, physical environment and academic quality of universities are considered essential for growing numbers of international students. This study aims to reveal and analyze the experiences of international students studying at graduate education step in Turkey. To this end, it is intended to describe and analyze the language proficiency, course period and thesis period experiences of international students studying in different fields of graduate programs and their perception on how their expectations were met or their apprehension. Phenomenology, one of the qualitative research methods, is used in the study. Semi-structured interviews were conducted in the study to flexibly gather data regarding the views of the participants and the differences between their experiences. Purposive sampling and snowball sampling methods were used together in forming a phase of the participant group. Interviews were conducted with 23 students from 18 different countries who are currently in İstanbul and studying in various departments. Descriptive analysis was used to analyze the data gathered from these interviews to examine the graduate education experience of the international students in Turkey. The educational experience of the students is primarily positive, and the students believe that they have received a high-quality education and they were provided with excellent opportunities. However, not being able to acquire academic writing skills or communicate with the professors sufficiently and the unconformity of the graduate education programs with the international educational context are some of the significant problems that were mentioned.
\end{abstract}

Keywords: higher education, international students, graduate programs, educational experiences

\section{Introduction}

There is an intense activity in the world to receive higher education (Altbach \& Knight, 2007; Bolsmann \& Miller, 2008; Jackson, 2013). While many students from Turkey go abroad to study, a significant number of students come to Turkey for educational purposes at the same time. A sharp increase is observed in the international student numbers in Turkey in recent years (Özoğlu, Gür, \& Coşkun, 2012). Approximately 108.000 international students are studying during 2016-2017 education term in Turkey where internationalization is considered to be a critical higher education policy, and it is supported. Student distribution is shown below.

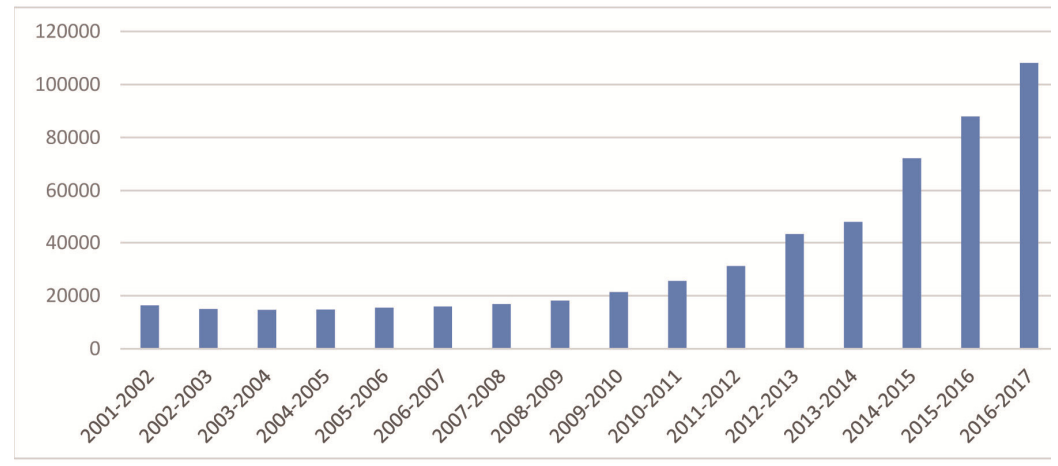

Figure 1. Number of international students in Turkey (2001-2017)

Source: YÖK (Higher Education Council) Statistics, n.d, retrieved from https://istatistik.yok.gov.tr/ 
Graduate education is the highest step in higher education and the people receiving graduate education forms the most qualified group of people in the society. Graduate education includes postgraduate and doctorate education. The ones who completed the postgraduate education are characterized as experts. The purpose of postgraduate education is to produce people with advanced research skills who have learned scientific literature in a discipline profoundly. Doctorate education, on the other hand, is the highest-level education in any field and expects the students to make original and qualified productions. It is also among the aims of doctorate education to up bring lecturers for universities. When the distribution of international students in Turkey in 2016-2017 education period is examined, it is observed that a great deal of those students is in Turkey for postgraduate education.

Table 1. Distribution of international students studying in Turkey in 2016-2017 education year according to the units they have received education from

\begin{tabular}{lllll}
\hline & Male & Female & Total & Total \% \\
\hline Associate & 3819 & 2380 & 6199 & 5.74 \\
Undergraduate & 50295 & 24826 & 75121 & 69.51 \\
Post Graduate & 12430 & 6700 & 19130 & 17.70 \\
Doctorate & 5310 & 2316 & 7626 & 7.06 \\
Total & 71854 & 36222 & 108076 & 100.00 \\
\hline
\end{tabular}

Source: ÖSYM (Student Selection and Placement Center) and YÖK (Higher Education Council) Statistics. n.d., retrieved from https://istatistik.yok.gov.tr/

As regards to the table, $75.25 \%$ of the international students in Turkey are studying in faculties and academies. The vast majority of these institutions are schools that provide four-years of education. The remaining $24.76 \%$ of the students are observed to continue their education in units providing postgraduate education. A good part of the international students in Turkey receives education provided by the Turkish government. Thanks to the Türkiye Scholarships program carried out by Presidency for Turks Abroad and Related Communities, more and more students come to Turkey for postgraduate education every year. The distribution of the students that receive this scholarship is shown below.

Table 2. Change in the number of undergraduate, pre-graduate and post-graduate students receiving Türkiye Scholarship between 2001-2014

\begin{tabular}{|c|c|c|c|c|c|}
\hline \multirow[b]{2}{*}{ Year } & \multicolumn{2}{|c|}{ Undergraduate and Pre-Graduate } & \multicolumn{2}{|c|}{ Post Graduate } & \multirow[b]{2}{*}{ Total } \\
\hline & Number & $\%$ & Number & $\%$ & \\
\hline 2001 & 727 & 76.13 & 228 & 23.87 & 955 \\
\hline 2002 & 684 & 70.23 & 290 & 29.77 & 974 \\
\hline 2003 & 803 & 67.71 & 383 & 32.29 & 1.186 \\
\hline 2004 & 920 & 69.38 & 406 & 30.62 & 1.326 \\
\hline 2005 & 847 & 70.00 & 363 & 30,00 & 1.210 \\
\hline 2006 & 1018 & 73.71 & 363 & 26.29 & 1.381 \\
\hline 2007 & 981 & 72.19 & 378 & 27.81 & 1.359 \\
\hline 2008 & 977 & 72.48 & 371 & 27.52 & 1.348 \\
\hline 2009 & 1432 & 75.33 & 469 & 24.67 & 1.901 \\
\hline 2010 & 1662 & 74.50 & 569 & 25.50 & 2.231 \\
\hline 2011 & 2277 & 74.83 & 766 & 25.17 & 3.043 \\
\hline 2012 & 2199 & 54.73 & 1819 & 45.27 & 4.018 \\
\hline 2013 & 2185 & 53.76 & 1879 & 46.24 & 4.064 \\
\hline 2014 & 1995 & 50.44 & 1960 & 49.56 & 3.955 \\
\hline
\end{tabular}

Source: Retrieved from Presidency for Turks Abroad and Related Communities [YTB] (2014). Türkiye Scholarships Statistics Almanac 2014.

With the Türkiye Scholarships, the number of postgraduate students receiving scholarships is increasing each year. When we examine the distribution levels of the scholarships, we see that there's a tendency towards postgraduate degrees. In 2011, one-fourth of the students who were granted scholarships were at the post-graduate degree, while half of the scholarships awarded in 2014 were for post-graduate education. Postgraduate education is examined under three main groups regarding similarity of the educational content and methods used: a) engineering and natural sciences, b) medical and health sciences and c) social and human sciences. According to 2014 data, 58\% of the international postgraduate students in Turkey was enrolled in institutes in social or human sciences fields. This indicates that Turkey is predominantly preferred for social science education (YTB [Presidency for Turks Abroad and Related Communities], 2014). Dimensions such as 
academic climate, academic processes, physical environment and academic qualities of the universities are considered and used as standards for international quality assurance of universities (Aktan \& Gencel, 2007). Therefore, the quality of the education is an important factor in meeting the expectation of the international postgraduate students. The more knowledge, skills, and competence the students gain with the postgraduate education they receive, the more students will come to that country for education. According to Beltekin \& Radmard (2013), international students have suggested that they could not get enough support when they individually needed attention, help or communication of the lecturers. Ramachandran (2011) stated that international students who are living in a different culture away from their parents are afraid of loneliness and failure. International students face not only academic difficulties but social and cultural difficulties as well (Ramburuth, 2001). According to Andrade (2006), academic achievement is an important factor when it comes to student adaptation. That also requires that the curricula and course content be reviewed by the international standards. Some studies have been conducted on international students' education and compliance issues in Turkey. These studies often included interviews with students at different levels of education and the results of the surveys conducted. In these studies, international students' problems related to different fields are usually discussed together. However, these studies may be mentioned in the following titles as from the issues they mainly discussed and the emphasis they made:

- Students' expectations, goals and perceptions of Turkey (Day, 2012; Diktaş, 2008; Günaydın, 2012; Karabayev \& Tutkun, 2001).

- Cultural, social and psychological adaptation experiences and problems (Açık, 1995; Otrar, Ekşi, Dilmaç, \& Şirin, 2002; Allaberdiyev, 2007; Annaberdiyev, 2006; Çöllü \& Öztürk, 2010; Kıroğlu, Kesten, \& Elma, 2010; Paksoy, Paksoy, \& Özçalıcı, 2012).

- Experiences and problems regarding education, learning and academic life experiences (Barut, Gökalp, Akdenk, \& Nazarov, 1999; Çağlar, 1999; Derman, 2010; Kılıçlar, Sarı, \& Seçilmiş, 2012).

- General intertanional student policy, supportive services and students' experience in financial matters (Levent \& Karaevli; Can, 1996; Günay, 2014)

When the field literature is elaborately examined, it is seen that most of the students are focused on social, cultural adjustment problems and language learning issues. There has been no study so far that evaluates the education of graduate students in Turkey with different dimensions of the education received (content and quality of courses, proficiency, and approach of the lecturers, research experience and skills, choosing a thesis topic and method, thesis writing process, etc.).

This study aims to reveal and analyze the experiences of international students studying at graduate education step in Turkey and to develop proposals to help to improve the education processes. To this end, it is intended to describe and analyze the international students';

- Experience regarding the Turkish education and language competence,

- Experience during course period (learning and communication), convenience of the lectures for learning, approach of the lecturers, research experience and skills,

- Experiences in the thesis process (choosing subject and methods, writing process, advisors)

- How their expectations are met and their perceptions

- What kind of supports they can get from the universities in Turkey and other institutions regarding their academic progress.

\section{Method}

Phenomenology, one of the qualitative research methods, is used in the study. Phenomenology pattern is a method used to examine phenomena we are aware of yet still need in-depth knowledge and understanding (Yıldırım \& Şimşek, 2011). In this study, how an international student experience receiving postgraduate education in Turkey is questioned constitutively in different dimensions. The phenomenological method focuses on the conscious everyday experiences of the individual and is used to reveal how this experience is perceived by the individual. In the study, semi-structured interviews were used to obtain participants' opinions and experience differences flexibly, and the findings were subjected to a descriptive analysis under themes.

\subsection{Participant Group}

Purposive sampling and snowball sampling methods were used together in forming a phase of the participant group. At the first stage in the snowball sample, the ones with the desired characteristics were identified, and 
interviews were conducted with these chosen individuals. Later on, these interviews will provide a source of information for the others to be sampled. In the second stage, these people are interviewed. This process continues in the form of a snowball (Balc1, 2011). Interviews were conducted with 23 people from 18 different countries who are currently in İstanbul and studying in different departments. 9 of the participants are female, and 14 are male. The table for the interviewed persons is given below. All interviews were conducted in April 2016. Average interview duration was nearly 20 minutes and the total duration of interviews was 457 minutes.

Table 3. Characteristics of sample participated in research

\begin{tabular}{|c|c|c|c|c|c|}
\hline Country & Gender & Age & University & Program & Education Status \\
\hline Kosovo & $\mathrm{M}$ & 26 & 29 Mayıs Uni. & TLL & Post Graduate \\
\hline Afghanistan & M & 25 & 29 Mayıs Uni. & TLL & Post Graduate \\
\hline Congo & M & 25 & Marmara Uni. & Commentary & Post Graduate \\
\hline Mali & M & 25 & İstanbul Uni. & Political Sciences & Post Graduate \\
\hline Indonesia & $\mathrm{F}$ & 24 & Marmara Uni. & Political History of the Middle East & Post Graduate \\
\hline Indonesia & M & 28 & İstanbul Uni. & Sociology & Post Graduate \\
\hline Albania & M & 31 & Çanakkale Uni. & History of Religions & Doctorate \\
\hline Cameroon & M & 26 & FSMVÜ & History & Post Graduate \\
\hline Ethiopia & M & 38 & FSMVÜ & Civilization Studies & Doctorate \\
\hline Ghana & M & 35 & Sakarya Uni. & Arabic Language & Doctorate \\
\hline Palestine & M & 30 & Sakarya Uni. & Islamic Law & Doctorate \\
\hline Tajikistan & M & & Trakya Uni. & International Relations & Post Graduate \\
\hline Albania & $\mathrm{F}$ & 35 & İstanbul Uni. & TLL & Doctorate \\
\hline Sudan & M & 28 & İstanbul Uni. & Sociology & Doctorate \\
\hline Mauritania & M & 25 & İstanbul Uni. & Islamic Law & Post Graduate \\
\hline Albania & M & 26 & İstanbul Uni. & International Relations & Post Graduate \\
\hline Japan & $\mathrm{F}$ & 27 & Marmara Uni. & Turkish Art & Post Graduate \\
\hline Azerbaijan & $\mathrm{F}$ & 24 & Marmara Uni. & Islamic Philosophy & Post Graduate \\
\hline Palestine & $\mathrm{F}$ & 25 & İstanbul Uni. & Social Structure and Development & Post Graduate \\
\hline Pakistan & $\mathrm{F}$ & & İstanbul Uni. & International Relations & Doctorate \\
\hline Somalia & $\mathrm{F}$ & 27 & İstanbul Uni. & Public Administration & Post Graduate \\
\hline Somalia & $\mathrm{F}$ & 24 & İstanbul Uni. & Public Administration & Post Graduate \\
\hline Uzbekistan & $\mathrm{F}$ & 29 & Marmara Uni. & Economy & Doctorate \\
\hline
\end{tabular}

Since the research was carried out based on the phenomenology pattern, semi-structured interview technique was used as the data collection tool. Semi-structured interviews provide researchers the chance to reveal experiences via probes regarding the facts (Creswell, 2013). In the interview form created in line with the objectives of the research, questions about the international language proficiency, the course period, the thesis process, how the expectations were met and the support towards academic progress were asked. The interview form created by the researcher was first applied to two students as a pilot study, and it was determined whether the questions were understandable or not. According to the feedback from the students, minor revisions were made to some questions.

\subsection{Analysis and Interpretation of the Data}

In the study, semi-structured interviews were conducted as it allows researchers to obtain participants' opinions and experience differences flexibly, and the interviews were recorded. The findings were subjected to a descriptive analysis under themes. To begin with, the interview records regarding the language competence, thesis process, how their expectations were met and the support for academic progress were examined, and pre-coding and axes were created. Afterwards, the codes were re-evaluated, and themes and cores were reached. In the final stage, the acquired findings were discussed in the context of regarding literature and proposals were developed to help to improve the quality of the educational experiences of the international postgraduate students.

\subsection{Validity and Reliability}

Expert advice was sought in this study on the development of data collection tools and the writing of data analysis results. While the research was being reported, it was aimed to improve the validity of the research by giving place to the citations in their original forms. Also, the responses given to the interview questions were coded separately by two researchers, and the interrater reliability studies were performed by comparing the encodings. 


\section{Findings}

The findings of the research are given under the titles of Turkish learning experiences, course period experience, thesis experience, support for academic progress, and general evaluation and the state of meeting the expectations of Turkish higher education.

\subsection{Turkish Learning Experiences}

Most of the graduate students stated that they learned Turkish in Turkey. The institution they received Turkish education is mostly the Türkçe ve Yabancı Dil Uygulama ve Araştırma Merkezi (TÖMER) (Turkish and Foreign Languages Practice and Research Center) which is under the body of Ankara University and specialized in teaching Turkish. While most of the students stated that they had a great difficulty in learning Turkish, students from the Turkic republics say that the period of language education was utterly comfortable for them. Although most of the participants have received language education, they state that their language skills are not adequate for them to qualitatively understand postgraduate courses and to perform their research tasks. "I think Turkish education is pretty good. I just thought after I started going classes. That period was a bit difficult. Otherwise, it is very good. I can even say perfect. I also took English lessons. It is even better than the way English is taught. Do you understand?" (KM, Cameroon, 26, History, PG)

A substantial part of the students suggest that the most difficult skill is the speaking among other reading, writing and listening skills. They do not find reading texts or comprehending what they hear as difficult. "I am in speaking. I even mhm, for example, academic Turkish, political Turkish and so on are better. However, my daily Turkish is not that good. I believe it is like that but not sure." (IM, Ethiopia, 38, Civilizations Studies, Doctorate).

Some participants have said that they had some daily Turkish education in the classes they took but that they have a hard time in classes as they often have to read academic texts. "As we learned daily Turkish more than academic Turkish, it may be the reason we are having difficulties now." (ŞR, Palestine, 30, Islamic Law, Doctorate).

For similar reasons, some participants believe that one year of Turkish education is not enough.

\subsection{Course Period Experience}

When the idea of course period experience was mentioned, firstly the relations with the lecturers and other students, the way the classes are conducted, homework, presentations, and access to resources and using them comes to mind.

\subsubsection{Relations with Lecturers and Other Students}

Communication and approach methods of the lecturers and the other students in the same department are of great importance for international students. Because people may feel less secure in places where they are strangers and feel emotionally fragile. All the interviewees stated that the faculty members are very good to them. The main concepts that attendees put forward regarding good treatment are the understanding, tolerance and less distance of power.

Some participants stated that faculty members have empathized and acted accordingly. "They are very good with strangers. Moreover, they know. For example, strangers can have so much trouble. With language. Alternatively, because it is a different kind of education. In their countries, maybe the courses are different, and something like that happens here. They are acting as I said to strangers." (MD, Mauritania, Islamic Law PG).

Some participants expressed that the lecturers treat them gently as they are stranger and that they try to help them: "Yes, there are. Yes, he is acting differently. He is doing us a lot more; he is a bit different because we are foreigners. They are more tolerant of us. They are helping. They know the issues we have." (BR, 26, Albania, $T L L, P G)$.

Some of the participants remarked that the lecturers are not distanced and that they can see or meet with their lecturer out of class and have a conversation with them. "But mmm outside I mean out of class, we are better with our lecturers, we are more comfortable. Because we can mmm talk to each other. For example, in Indonesia, lecturers I mean professors are more mmm busy. That is why mhm that is why we mhm and lecturer almost don't talk at all in Indonesia when outside." (DT, 28, Indonesia, Sociology PG).

One participant, on the other hand, thinks that although the lecturers treat them well, there is no real communication and sharing between them. "I do not know because we are foreigners, but there is not much connection between lecturers and us. We have very little connection really" (AR, 35, Ghana, Arabic Language Doctorate). 
In addition to cultural differences, the excess of teaching load of faculty members and a number of courses students take may limit the interaction between faculty members and students. "A teacher is giving many lectures, like lessons from morning to night, and so on. It becomes too late for us" (AA, 27, Japan, Turkish Art Doctorate).

When the question "Do you feel shy, lonely when you are around your friends?" was asked, participants generally express that they are communicating with their friends easily.

\subsubsection{Lectures, Homework and Presentations}

There are various opinions regarding the lectures, homework, and presentations in postgraduate education. It is observed that most of the students have difficulty in speaking Turkish and this is affecting their lecture performances. In general, the participants think that the quality of education is high, and the instructors are cumulative and qualified. Especially those in Turkish Language and Literature program are seen to have this idea. However, some participants complained that the instructors are very passive in the undergraduate courses, that they just give assignments to the students and withdrawn, and that the courses consist only of student presentations. "I have a year course. Around twelve classes. Those classes are not enough anyway. Postgraduate lecturers always demand from you. They do not talk much. They want you to do it." (BH, 27, Tajikistan, International Relations Post Graduate).

Also, some participants express that even though there are many homework and presentations, the presentations are too descriptive and there is no field study or analysis. "Academy is as if it was a high school. ... Lecturers talk, and we listen, that's it. There are so, so much homework but just for us, it's just like high school homework. We just memorize, memorize texts and sometimes we give presentations, but they are just general. We don't do any research." (Nabilia, 24, Indonesia, Political History of the Middle East Post Graduate). "No analysis? Not much. There is but just a little. That's why I didn't really like those general presentations. Because in Indonesia, the analysis is important to us. How? The analysis is important; most points are from there." (DT, 28, Indonesia, Sociology $P G)$ "

Some participants think that the curriculum largely covers the subjects of Turkey, that it remains local, and makes learning difficult. "I do not think so. Mhm, for instance, $\mathrm{mhm}$ in the first semester mhm everything is about Turkey. For example, the social life, change in Turkey I mean how the change was observed and happened in time during Ottoman era." (DT, 28, Indonesia, Sociology PG) According to that participant, the curricula were prepared for Turkish students, and they are not sensitive enough towards the needs of international students. That does not comply with the internationalization strategy in higher education.

\subsubsection{Access to Resources}

The access of the students to resources that are in academically prominent languages or in that country's language affects the education quality perception of the international students. Countries attracting the most international students are known to provide vast opportunities in terms of academic resources. Almost all the participants have said that there is a wealth of opportunities in Turkey when it comes to accessing academic resources and lecture materials. They are content that there are numerous Turkish books and articles, access to English resources and many books translated from English to Turkish. "We can find them easily, and there are Turkish books. There are articles and English, most importantly English books and resources that are easily found... For example, there are mhm English books there, translated into Turkish, there are many such books. But in Indonesia we only have to read original books, so we have to read. We need to read English books. There are Turkish books, in this place very comfortable. I mean very good like this" (NA, 24, Indonesia, Political History of the Middle East $P G)$.

However, a student in need of French resources has found it difficult to access such resources: "Apart from university libraries, some private libraries also make access to resources very easy. I had no problems as there was ISAM. I was able to access the resources that the lecturers mentioned. I did not do anything. I had no problems." (BR, 26, Albania, TLL, PG).

\subsection{Thesis Period Experience}

Almost all the participants interviewed were able to choose their own thesis topic. Yet, some institution administrators have used their initiatives in choosing student advisors. "...after the first semester, we got a message. Write on the topic you like. Also, state three advisors you want. Whomever you want the most should be the first one on the list. So, we wrote all they asked for and sent it. Then I went on the second semester. Lecturer says he cannot see me on his system. I called the institute. They said. Another advisor was appointed for you already." (YZ, Uzbekistan, 29, Economics, Doctorate). 
Most of the participants in the thesis period say that they can meet with the advisors when they need and that they often do periodic interviews. However, one participant complains that the advisor has not taken any action unless they request it. "Yes, but my advisor is not really approaching me. They are not approaching me. They never ask anything unless I go to see them. They do not tell me to do anything. A month, two months never tries. Only when they call me. When I call them." (AR, 35, Ghana, Arabic Language Doctorate).

Academic competencies in Turkey are inadequate to support post-graduate students who want to work in different languages. One student stated that they wanted to write their thesis in French, but they had to write the thesis in Turkish instead because there was not any lecturer to provide consultancy in French. "I did not want to write my thesis in Turkish, but I could not find a teacher who could write French." (AD, 26, Mali, Political Sciences, $P G)$.

Some of the students interviewed say it is very difficult to write Turkish academic texts. For this reason, they stated that their advisors allowed them to prepare their thesis in English and then translate it into Turkish. When the subjects that the students study in their thesis are examined, it is seen that the subjects helping students to learn and deepen and helping them to recognize the social structure of Turkey are chosen.

\subsection{Support for Academic Progress}

The educational experience of international students can vary considerably depending on the possibilities of the country and the city in which they live. The presence of institutions providing academic, social and cultural support other than universities also affects students' perceptions of education. Most of the participants are benefiting from Türkiye Scholarships or receiving scholarships from various institutions in Turkey. A significant part of them are attending courses offered by local governments other than the university they are attending, and they can receive supplementary training in various NGOs depending on their interests.

One of the students interviewed stated that they participated in extra training within the scope of Turkey scholarships, that they received education from another public institution and participated in the events organized by an NGO. "Yes, I can. Because now Türkiye Scholarships, courses, programs do things, organize, with foundations, institutions. We are going, last year a few, for example, in the archive of the Prime Minister was an Ottoman course, we also joined them. Then Selami Ali Foundation organized something, organized the program, and we joined it. Very good." (BR, Albania, TLL PG).

A student from Indonesia also says that they know about many courses out of university and that they can benefit from them, and that Turkey has a wealth of possibilities in this sense. The fact that these courses are usually free is also a source of satisfaction for the student. "This is a good example, as in Turkey, the associations are very easy for the students there. For example, there is the Ensar Foundation; there is Ismek. So, we have conferences, seminars, summer school. It is all free. So, it is very good for foreign students."... "There is the Ottoman Archive here, for example, in Süleymaniye" (DT, 28, Indonesia, Sociology PG).

"I attended certain seminars, courses, and training in non-governmental organizations in associations in specific locations for academic development. I followed certain courses. I also tried to attend some seminars. It is like that and also every year mhm there is something organized by that YTB, an academic program. It has begun about these times. It goes on one and a half months, two months. There are tutors who are experts in each field and come to teach their lectures in their own fields. (FH, 25, Afghanistan, Turkish Language, and Literature $P G)$.

In these statements, it is observed that the participants find their city rich in support for academic progress outside the university. Nevertheless, it may be said that the participants from cultures similar to the culture of Turkey are benefiting more from these opportunities.

\subsection{General Evaluations and the State of Meeting the Expectations of Turkish Higher Education}

Participants often find the quality of education to be high after questions regarding the different elements of education and the environment, and when they are asked to make an overall evaluation. "In this way education is sufficient for me in Turkey. In particular, we, the lecturers are always helping us up to now. Resources, I mean, when doing homework, they, I mean, understand that we are strangers. It is very good, educational quality. I am very pleased." (ILL, Sudan, Sociology Doctorate).

That Turkey is considered as an important actor in the Middle East and that it is an Islamic country despite its similar structure to Europe, students are attracted to Turkey. "It is not hard for a Muslim. The life mhm here is just like Europe. No, like Europe mhm but Muslim." (DT, 28, Indonesia, Sociology PG). 
The religious-cultural similarity and hospitality may be considered among the justifications of high contendness and meeting of the expectations. They say "They see us as brothers and sisters. I did not go other countries, but I know. For example, when I ask where a restaurant is, many people show me or take me there. However, in the States or Europe, I do not know." (AD, 26, Mali, Political Sciences PG).

Some graduate students see Turkey as a stepping stone for the transition to Europe and express their desire to go to European countries for their doctoral studies. However, when compared to their friends who have gone to different countries as international students, they often consider themselves very lucky, and they are happy that they chose to come here. "So now I have had a few more opportunities after finishing the course. I had means of going to different countries. However, there were some obstacles for some; I also didn't want some of them. That way, when I look back, there are my friends who went there." .... "One of them went to India, or Turkmenistan, Kazakhstan. There are more people going to different countries, but I feel lucky again because I came here." (FH, 25, Afghanistan, Turkish Language, and Literature PG).

\section{Discussion}

International students who took place in interviews from different universities in İstanbul studying at different departments in postgraduate education think that they are generally provided with an education of good quality and that they are in an academically and socially rich environment where they are supported regarding human affairs. When the literature regarding the subject is examined, according to Kirby, Woodhouse, \& Ma (1999), the leading problems encountered by the international students are understanding the language of the country they are in and acquiring academic writing and reading skill in that language. To overcome this problem, international students might be required to take classes such as Academic Writing Skills, after the basic Turkish course in Turkey. This will make it easier for students to learn Turkish as an academic language.

The students who were interviewed expect the teaching staff to be more active in teaching and guiding the students. Reay et al. (2001) emphasized on the guidance needs of international students in a study they conducted and stated that in situations where the teachers or academic advisors have a passive role, students are challenged in the orientation and adaptation process. The most significant finding of this study is that the curricula in postgraduate education in Turkey are prepared for the Turkish people and that it does not comply with the needs and interests of international students. According to Organisation for Economic Co-operation and Development [OECD] (2011) report, the reputation the University student applies to, and the program's flexibility regarding duration and curriculum as well as its contribution to the professional development of the program is also an important influence on the choice of university for international students. Internationalization of universities should be supported on many different levels such as introduction, curriculum development, international student support services and education of university personnel (Özoğlu et al., 2012). In a study they conducted, Luxon \& Peelo (2009) stated that revising the curriculum is an important step in turning education and learning life into a more productive one for the international students and meeting their needs.

When the students' experience of the thesis stage is examined, it can be said that the thesis studies may have an advantage for the students if they have selected or directed to select Turkey oriented subjects, but it is considered that the studies conducted may make an only limited contribution to the academic accumulation in Turkey. It may be considered that foreign students will not be able to easily compete with their Turkish peers on the social structure, politics, economy, culture, history, and literature of Turkey. This can lead to failure of benefiting from international student potential regarding academic policies. In this context, it is necessary for lecturers, especially those who are counseling international students, to take more care in guiding the academic processes of these students. Also, when choosing a research and thesis topic, it will be more appropriate for the students to prioritize international disciplines rather than the local issues using the advantage of language.

International students face more stress, anxiety, loneliness, fear of failure and social adjustment problems than local students (Burns, 1991; Osterman, 2001, Samuelowicz, 1987). In such situations, the support provided by local students and the surrounding community is a significant positive influence on the adaptation of international students (Al-Sharideh et al., 1998; Andre, 1991; Jenkins \& Galloway, 2009; Yanhong Li \& Kaye, 1998). The availability of the various supports offered by local organizations and non-governmental organizations in the city where most of the participants are present indicates a positive atmosphere, and that helps to minimize the social and psychological adaptation problems. That these environmental factors are positive, might be emphasized in Turkey's strategy to attract more international students.

On the basis of the study results, using the experience of the international postgraduate students, the positive sides and inadequacies of the education were revealed after profoundly examining the dimensions of postgraduate education towards the international students in Turkey. Thus, it is thought that it will contribute to 
increasing the international quality assurance of the education and will help to attract more students to the country. The findings of the research indicate that further qualitative and quantitative research needed on the education quality perceptions of international students. International comparisons about educational quality perceptions of students will also broaden the vision of higher international education policy.

\section{References}

Açık, F. (1995). Özbekistan'dan eğitim-öğretim amacıyla Türkiye'ye gelen öğrencilerin dil-kültür-uyum problemleri ve çözüm teklifleri. (Yayımlanmamış yüksek lisans tezi). Gazi Üniversitesi, Ankara.

Aktan C. C., \& Gencel, U. (2007). Yükseköğretimde akreditasyon. İzmir: Yaşar Üniversitesi Yayınları.

Al-Sharideh, K. A., \& Goe, W. R. (1998). Ethnic communities within the university: An examination of factors influencing the personal adjustment of international students. Research in Higher Education, 39(6), 699-725. https://doi.org/10.1023/A:1018714125581

Allaberdiyev, P. (2007). Türk Cumhuriyetlerinden Türkiye'ye yüksek öğrenim görmeye gelen ögrrencilerin uyum düzeylerinin incelenmesi. (Yayımlanmamış yüksek lisans tezi). Gazi Üniversitesi, Ankara.

Altbach, P. G., \& Knight, J. (2007). The Internationalization of higher education: motivations and realities. Journal of Studies in International Education, 11(3/4), 290-305. https://doi.org/10.1177/1028315307303542

Andrade, M. S. (2006). International students in English-speaking universities: Adjustment factors. Journal of Research in International Education, 5(2), 131-154. https://doi.org/10.1177/1475240906065589

Andre, R. (1991). Positive solitude: A practical program for mastering loneliness and achieving self-fulfilment. New York: Harper Collins.

Annaberdiyev, D. (2006). Türkiye'de eğitim gören Türk Cumhuriyetleri ve Türk üniversite ögrencilerinin psikolojik yardım arama tutumları, psikolojik ihtiyaçları ve psikolojik uyumlarının bazı değişkenler açısından incelenmesi (Yayımlanmamış yüksek lisans tezi). Ege Üniversitesi, İzmir.

Balc1, A. (2011). Sosyal bilimlerde araştırma yöntem, teknik ve ilkeler. Ankara, Pegem Akademi.

Barut, Y., Gökalp, M., Akdenk, M., \& Nazarov, A. (1999). Türkiye'de öğrenim gören Türk cumhuriyetleri ve akraba topluluklarından gelen öğrencilerin öğretim programlarına yönelik bakış açılarının incelenmesi (Samsun 19 Mayıs Üniversitesi Örneği). In M. K. Öke (Ed.), Geçiş sürecinde Orta Asya Türk Cumhuriyetleri (ss. 460-467). Alfa Yayıncilık.

Beltekin, N., \& Radmard, S. (2013). Türkiye'de lisansüstü eğitim gören uluslararası öğrencilerinin üniversiteye ilişkin görüşleri. Elektronik Sosyal Bilimler Dergisi, 12(43), 250-269.

Bolsmann, C., \& Miller, H. (2008). International student recruitment to universities in England: discourse, rationales and globalization. Globalisation, Societies and Education, 6(1), 75-88. https://doi.org/10.1080/14767720701855634

Burns, R. (1991). Study and stress among first year overseas students in an Australian university. Higher Education Research \& Development, 10(1), 61-77. https://doi.org/10.1080/0729436910100106

Çağlar, A. (1999). Türk üniversitelerinde öğrenim gören Türk Cumhuriyetleri ve akraba toplulukları öğrencilerinin sorunları. Amme İdaresi Dergisi, 32(4), 133-169.

Can, N. (1996). Türkiye'de yüksek öğrenim gören yabancı uyruklu öğrencilerin sorunları ve örgütsel yapı. Erciyes Üniversitesi Sosyal Bilimler Enstitüsü Dergisi, 7, 503-512.

Çöllü, E. F., \& Öztürk, Y. E. (2010). Türk Cumhuriyetleri, Türk ve akraba topluluklarından Türkiye’ye yüksek öğrenim görmek amacıyla gelen öğrencilerin uyum ve iletişim sorunları (Konya Selçuk Üniversitesi örneği). Journal of Azerbaijani Studies, 1-2, 223-239.

Creswell, J. W. (2013). Research design: Qualitative, quantitative, and mixed methods approaches. Thousand Oaks, California: Sage publications.

Derman, S. (2010). Yabancı uyruklu öğrencilerin Türkiye Türkçesi öğreniminde karşılaştıkları sorunlar. Selçuk Üniversitesi Illahiyat Fakültesi Dergisi, 29, 227-247.

Diktaş, G. (2008). Sakarya Üniversitesi'nde ögrenim gören Türk dünyası ve akraba topluluklarından gelen ögrrencilerdeki Türkiye imajı (Yayımlanmamış yüksek lisans tezi). Sakarya Üniversitesi, Sakarya.

Günay, B. (2014). Türkiye'de okuyan uluslararası ögrencilerin sorunları. İ.Ü. Avrasya Enstitüsü Yayınları.

Günaydın, A. (2012). Niçin Türkiye? Türkiye Burslusu Uluslararası Öğrencilerin niyet mektuplarında Türkiye 
algısı: ODTÜ ve Boğaziçi Üniversitesi Öğrencileri örneği. Ankara: T.C. Başbakanlık Yurtdışı Türkler ve Akraba Topluluklar Başkanlı̆̆

Jackson, D. (2013). Business graduate employability. Where are we going wrong? Higher Education Research \& Development, 32, 776-790. https://doi.org/10.1080/07294360.2012.709832

Jenkins, J. R., \& Galloway, F. (2009). The adjustment problems faced by international and overseas Chinese students studying in Taiwan universities: A comparison of student and faculty/staff perceptions. Asia Pacific Education Review, 10, 159-168. https://doi.org/10.1007/s12564-009-9020-5

Karabayev, B., \& Tutkun, Ö. F. (2001). Türk Cumhuriyetlerinden gelen öğrencilerin Türkiye Cumhuriyeti vatandaşlarına karşı taşıdıkları kalıp yargılar. Bilig Türk Dünyası Sosyal Bilimler Dergisi (SSCI), 18, 1-27.

Kılıçlar, A., Sarı, Y., \& Seçilmiş, C. (2012). Türk dünyasından gelen öğrencilerin yaşadıkları sorunların akademik başarılarına etkisi: Turizm öğrencileri örneği. Bilig Türk Dünyası Sosyal Bilimler Dergisi, 6, 157-172.

Kirby, J. R., Woodhouse, R. A., \& Ma, Y. (1999). Studying in a second language: The experiences of Chinese students in Canada. In D. A.Watkins \& J. Biggs (Eds.), The Chinese learner: Cultural, psychological and contextual influences (pp. 141-158). Hong Kong: Australian Council for Educational Research.

Kıroğlu, K., Kesten, A., \& Elma, C. (2010). Türkiye'de öğrenim gören yabancı uyruklu lisans öğrencilerinin sosyo-kültürel ve ekonomik sorunları. Mersin Üniversitesi Eğitim Fakültesi Dergisi, 6(2), 26-39.

Levent, F., \& Karaevli, Ö. (2013). Uluslararası Öğrencilerin Eğitimine Yönelik Politikalar ve Türkiye İçin Öneriler. Marmara Üniversitesi Atatürk Ĕgitim Fakültesi Eğitim Bilimleri Dergisi, 38(38), 97-118.

Luxon, T., \& Peelo, M. (2009). Internationalization: its implications for curriculum design and course development in UK higher education. Innovations in Education and Teaching International, 46(1), 51-60. https://doi.org/10.1080/14703290802646172

Organisation for Economic Co-operation and Development [OECD]. (2011). Education at a glance 2011: OECD indicators. OECD Publishing.

Osterman, K. F. (2001). Students' need for belonging in the school community. Review of Educational Research, 70, 323-367. https://doi.org/10.3102/00346543070003323

Otrar, M., Ekşi, H., Dilmaç, B., \& Şirin, A. (2002). Türkiye'de öğrenim gören Türk ve akraba topluluk öğrencilerinin stres kaynakları, basa çıkma tarzları ile ruh sağlığı arasındaki ilişki üzerine bir araştırma. Kuram ve Uygulamada Eğitim Bilimleri Dergisi, 2(2), 477-499.

Özoğlu, M., Gür, B. S., \& Coşkun, İ. (2012). Küresel eğilimler ışı̆ğnda Türkiye'de uluslararası öğrenciler. Ankara: SETA Siyaset Ekonomi ve Toplum Araştırmaları Vakfı Yayınları.

Paksoy, H. M., Paksoy, S., \& Özçalıcı, M. (2012). Türkiye'de yüksek öğrenim gören yabancı uyruklu öğrencilerin sosyal sorunları: GAP bölgesi üniversiteleri örneği. KSÜ IİBF Dergisi, 2, 85-94.

Ramachandran, N. T. (2011). Enhancing international students' experiences: An imperative agenda for universities in the UK. Journal of Research in International Education, 10(2), 201-220. https://doi.org/10.1177/1475240911413204

Ramburuth, P. (2001). Language diversity and the first-year experience: Implications for academic achievement and language skills acquisition. Journal of the First-Year Experience, 13(2), 75-93.

Reay, D., David, M., \& Ball, S. (2001). Making a difference?: Institutional habituses and higher education choice. Sociological Research Online, 5(4), 126-142. https://doi.org/10.5153/sro.548

Samuelowicz, K. (1987). Learning problems of overseas students: Two sides of a story. Higher Education Research \& Development, 6(2), 121-133. https://doi.org/10.1080/0729436870060204

Yanhong Li, R., \& Kaye, M. (1998). Understanding overseas students' concerns and problems. Journal of Higher Education Policy and Management, 20(1), 41-50. https://doi.org/10.1080/1360080980200105

Yıldırım, A. \& Şimşek, H. (2011). Sosyal bilimlerde nitel araştırma yöntemleri. Ankara, Seçkin Yayıncılık.

YTB-T. C. Başbakanlık Yurtdışı Türkler ve Akraba Topluluklar Başkanlığı [Presidency for Turks Abroad and Related Communities]. (2014). Türkiye burslarl istatistik yıllı̆̆ 2014. 


\section{Copyrights}

Copyright for this article is retained by the author(s), with first publication rights granted to the journal.

This is an open-access article distributed under the terms and conditions of the Creative Commons Attribution license (http://creativecommons.org/licenses/by/4.0/). 